\title{
Juan Del Río Martín, Nuevos apuntes para la vida (Colec. Popular 242), Madrid, BAC, 2019, 465 pp.
}

Este libro, como señala el título, son apuntes "nuevos", pues ya el autor publicó en su día otro repertorio de escritos semejantes, redactados en los primeros tiempos de su ministerio episcopal. Ahora da a la luz otra cosecha, fruto de sus constantes esfuerzos de estudio y reflexión durante el 2006 y el 2018. Y es que, por formación y convicción, en el ejercicio de su servicio pastoral, el Prelado ama comunicar, compartir ideas, propagar entusiasmo, dejar constancia de sus vivencias y perplejidades. Y esto no por estrategia humana sino por vocación evangelizadora. Este libro es una preclara muestra de ese espíritu misionero, que lo lleva con asiduidad a esparcir copiosamente la semilla del Evangelio, para que aquellos que tiene encomendados a su cuidado apostólico se adentren de su mano en el Corazón de Dios y en la hondura humana, no queden a oscuras en las arduas cavidades de las elecciones personales y sean pujante levadura en el meollo de las encrucijadas sociales.

Esta publicación recoge 216 breves e incisivas consideraciones, espigadas entre otras muchas redactadas por el Arzobispo Castrense de España, por Don Luis Manuel Romero Sánchez, Director del Secretariado de la Comisión Episcopal de Apostolado seglar de la Conferencia Episcopal Española, que asimismo se ha encargado del prólogo del volumen, vertebrando y agrupando también las temáticas de esta obra en tres grandes bloques: vida cristiana; año litúrgico y jornadas eclesiales; iglesia y sociedad.

Estas páginas no son un alarde de abstracción ni dan pábulo a piruetas teóricas. Están más bien tejidas con hechos concretos de la vida diaria, al hilo de noticias cotidianas o de eventos precisos, sobre los que vale la pena detenerse para sopesarlos, en un ejercicio de lúcido discernimiento. Tienen su cuna, por consiguiente, en el quehacer pastoral del Prelado, que tanto en su primera sede, Jerez de la Frontera, como ahora al frente del Ordinariato Militar de España, ha multiplicado sus intervenciones escritas para ofrecer puntualmente a su grey claridad y criterios para comprender desde el Evangelio las cuestiones candentes que surgen con el pasar de los días. Son apuntes hilvanados con cordialidad y amplitud de miras, para dejar constancia con frecuencia de sucesos universales, pero no solo. El Prelado vierte su luz también en jalones de la intrahistoria, en esos hitos minúsculos, pero que de ordinario condicionan o están en la raíz de giros sociales o eclesiales de mayor envergadura. Con sus escritos lo que en realidad pretende el autor es sembrar esperanza en los corazones atribulados; dar respuesta a las nobles inquietudes que anidan en el alma humana; reiterar los grandes principios de la doctrina social de la Iglesia; deshacer entuertos; avivar el buen humor en medio de una sociedad que a menudo está encarcelada en el pesimismo. Se subraya de esta manera, y me parece que puede ser la condensación de 
estas páginas, la firme voluntad del Arzobispo de proponer la Buena Noticia de Jesucristo como quicio para una existencia humana con sentido y una sociedad hija de la paz, la justicia y la solidaridad.

Cuando toma la pluma, el autor adereza sus escritos no solo con amplias dosis de espontaneidad y sentido común, sino también con citas acrisoladas al calor de la sabiduría bíblica, popular y teológica. Usa, sobre todo, abundantes ideas del magisterio papal, traído a colación con tino y agudeza para mostrar que el gran tesoro de la Iglesia es la comunión. Efectivamente, con Pedro y bajo Pedro, el cristiano anda por caminos seguros, encontrando en la palabra del Obispo de Roma acicate y bálsamo para afrontar las problemáticas cotidianas con acierto y humildad.

En un mundo de prisas y multiplicidad de compromisos, un libro como el que nos ocupa es ideal para tomarlo como compañero. Sus capítulos enjundiosos lo permiten, teniendo la extensión adecuada para no cansar. Antes bien, cada uno de ellos aviva la sed del lector para que continúe avanzando en la lectura.Y, al respecto, se nota que el autor está versado en el mundo de la prensa, caracterizándose el despliegue de su pensamiento por un estilo vivaz y no alambicado, rico de matices y, al mismo tiempo, amante de la frescura y la sencillez, con frases certeras, yuxtapuestas y breves, muy en el estilo de Azorín. Todos estos ingredientes anclan el pensamiento de Mons. Del Río a las aspiraciones de quien recorre estas páginas con ansias de aprender.

En la primera parte de este volumen, como arriba asentado, se recolectan apuntes del Prelado sobre cuestiones cotidianas, surgidas del correr de los días, y que abarcan temáticas familiares o problemáticas personales. El autor se detiene en virtudes y vicios, retos e inercias, flaquezas y proezas humanas. Cuando se adentra en una vertiente, el Arzobispo lo hace buscando poner de manifiesto lo que construye y beneficia, sin caer en el tono gris que no pocas veces embarga nuestras vidas y nos impide aspirar a la excelencia y la positividad.

La segunda parte de este libro ofrece claves para vivir con auténtico sentido eclesial momentos álgidos del año litúrgico, invitando al lector a centrarse en lo esencial y clavar los ojos en Cristo, que es el autor y consumador de nuestra salvación (cf. Heb 12,2; Ef 2,8-9). Respiran estas páginas un profundo amor al Redentor y a su Esposa, la Iglesia, formada por santos y pecadores, una Iglesia samaritana, una Iglesia evangelizada y evangelizadora, una Iglesia que desea ser fiel a la misión asignada por su divino Fundador, por lo cual se afana por desligarse de la mundanidad, para que su rostro no quede afeado, sino nimbado de la luz que recibe de Aquel que en la Cruz dio supremo testimonio de amor y compasión.

Y es justamente la componente eclesial la que se desarrolla de manera más amplia en la parte final de esta obra, dedicada a glosar el camino del pueblo de Dios peregrino en el mundo, abierto a las interpelaciones que 
le llegan de la sociedad y sus instituciones, que atañen a ricos y pobres, a ancianos y jóvenes, enfermos, personas sin techo $u$ hogar... La Iglesia tiene multitud de interlocutores y no reputa ajeno nada de lo humano, pues no existe para aislarse. Más bien apuesta por el diálogo y el coloquio franco con sus contemporáneos para brindarles, sin aspavientos, el tesoro que a ella la enriquece, y que no es otro que la Palabra de Cristo, fuente de plenitud y de vida auténtica, artífice de paz consumada. En este tercer bloque se abordan también cuestiones de religiosidad popular, tratadas siempre con profundo conocimiento, dada la notable experiencia pastoral del Prelado en este campo.

Concluyendo, este volumen es una variada y rica compilación de criterios y sugerencias para tomar la vida en serio y huir de planteamientos superficiales o anodinos. Para ello, su autor anima continuamente a pasar por este mundo imitando a Jesús, que no se cansó de abrir horizontes de bondad y nos legó como herencia el distintivo de la caridad.

Estas páginas, cuyos destinatarios pueden ser sacerdotes, laicos o consagrados, jóvenes o personas que viven en soledad, sirven de compañía y hacen pensar a los miembros de la Iglesia. Pero no se limitan a ellos. A los que ya forman parte de la familia eclesial, esta publicación los alienta con vehemencia a recordar que el bautismo, puerta que nos otorga la filiación divina y la ciudadanía eclesial, es un sacramento con repercusiones en lo cotidiano, para que no olvidemos que somos hijos de la luz e hijos del día. Por ello hemos de difundir la fragancia de las obras de misericordia, ser oyentes de la Palabra, místicos en medio de la acción, apóstoles y heraldos de la mejor de las noticias: el amor ilimitado de Dios por el hombre, en especial por el postergado y desfavorecido. Él se inclina con ternura hacia cada uno de nosotros. Tiene deseos de vernos a todos unidos como familia. Sueña que esta tierra sea una casa común, en donde nadie se sienta excluido, rezagado u olvidado, sino que sea valorado en su dignidad inviolable. Estas páginas, en fin, por la calidez de sus planteamientos, invitan igualmente a los que no conocen a Cristo ni sintonizan con la Iglesia a no caer en tópicos manidos sobre la vida cristiana ni a quedarse herméticamente cerrados en sus razonamientos, suscitando apertura e invocando el respeto. Lo cual es un gran servicio del autor a muchos que, como los Magos de Oriente, buscan para sus vidas y su entorno una novedad benéfica (cf. Mt 2,1-12).

Fernando Chica Arellano

Observador Permanente de la Santa Sede ante la FAO, el FIDA, y el PMA arellano@libero.it 